\title{
Euphorbia mbuinzauensis, a new succulent species in Kenya from the Synadenium group in Euphorbia sect. Monadenium (Euphorbiaceae)
}

\author{
Neng Wei ${ }^{1,2,3}$, Fredrick Munyao Mutie ${ }^{1,3}$, Geoffrey Mwachala ${ }^{4}$, \\ Olwen M. Grace², Guang-Wan Hu ${ }^{1,5,6}$, Qing-Feng Wang ${ }^{1,5,6}$
}

I Key Laboratory of Plant Germplasm Enhancement and Specialty Agriculture, Wuhan Botanical Garden, Chinese Academy of Sciences, Wuhan, CN-430074, China 2 Royal Botanic Gardens, Kew, Richmond, Surrey, TW9 3AE, UK 3 University of Chinese Academy of Sciences, Beijing, CN-100049, China 4 East African Herbarium, National Museums of Kenya, P.O. Box 451660-0100, Nairobi, Kenya 5 Center of Conservation Biology, Core Botanical Gardens, Chinese Academy of Sciences, Wuhan, CN-430074, China 6 Sino-Africa Joint Research Center, Chinese Academy of Sciences, Wuhan, CN-430074, China

Corresponding authors: Guang-Wan Hu (guangwanhu@wbgcas.cn), Qing-Feng Wang (qfwang@wbgcas.cn)

Academic editor: Dmitry Geltman | Received 17 June 2021 | Accepted 30 August 2021 | Published 11 October 2021

Citation: Wei N, Mutie FM, Mwachala G, Grace OM, Hu G-W, Wang Q-F (2021) Euphorbia mbuinzauensis, a new succulent species in Kenya from the Synadenium group in Euphorbia sect. Monadenium (Euphorbiaceae). PhytoKeys 183: 21-35. https://doi.org/10.3897/phytokeys.183.70285

\begin{abstract}
Euphorbia mbuinzauensis, a succulent new species of the Synadenium group in Euphorbiaceae from Makueni County, Kenya, is described and illustrated. Morphologically, it is most similar to E. pseudomollis, but differs mainly by its shrubby habit (up to $4 \mathrm{~m}$ ), abaxial leaves surfaces with densely stellate hairs, 2-4-forked cymes, smaller bracts (ca. $2.5 \times 3.0 \mathrm{~mm})$, smaller cyathia (6 mm wide), crimson glands without narrow smooth margin, smaller fruits $(\mathrm{ca} .8 \times 7 \mathrm{~mm}$ ) and ovoid seeds (ca. $1.8 \times 2.2 \mathrm{~mm}$ ). Furthermore, we performed a molecular phylogenetic analysis of the Synadenium group in Euphorbia sect. Monadenium, based on complete nuclear ribosomal DNA (nrDNA) datasets. This phylogenetic inference also supports it to be a distinct species. The new species is assessed as Endangered using the IUCN criteria.
\end{abstract}

\section{Keywords}

East Africa, endangered, molecular phylogeny, succulents, Synadenium, taxonomy

Copyright Neng Wei et al. This is an open access article distributed under the terms of the Creative Commons Attribution License (CC BY 4.0), which permits unrestricted use, distribution, and reproduction in any medium, provided the original author and source are credited. 


\section{Introduction}

Synadenium Boiss. (in de Candolle (1862: 187)), was a previously recognized genus of Euphorbiaceae, confined to east and southern tropical Africa, with 14 closely related species (Carter and Leach 2001). Synadenium is readily distinguishable from other genera in Euphorbieae subtribe Euphorbiinae by the unique ring-shaped fused glands in the cyathium (Jones and Smith 1969; Carter 1988; Carter and Leach 2001). It has been regarded as a taxonomically difficult genus (Govaerts et al. 2000), since the differences between the species appear to be slight, especially when observing dried herbarium specimens only. Moreover, Brown et al. (1909) assumed that Synadenium species are locally endemic and probably more numerous than previously known (13 spp. at that time), given their great resemblance to one another, which may have resulted in some of them being overlooked.

Besides emphasizing leaf and cyme-branching characters, Carter and Leach (2001) suggested that emphasis should also be placed upon the habit, the shape and size of the cyathium, the color and furrowing of the involucral glands, and features of the capsules and seeds. Unfortunately, relatively few specimens have been prepared and deposited in herbaria, especially fruiting ones (Carter 1988). Although regional taxonomic treatments have been done, Synadenium has never been comprehensively monographed, and was regarded as a poorly known group.

Webster (1967) and Croizat (1972) questioned the delimitation of Synadenium and Monadenium as distinct genera and suggested, based on morphological similarities, that they were closely related to Euphorbia sect. Tirucalli. Analysis of molecular data over the past two decades (Steinmann and Porter 2002; Bruyns et al. 2006, 2011; Zimmermann et al. 2010; Horn et al. 2012; Dorsey et al. 2013; Wei et al. 2021), have all shown that the genera Endadenium, Monadenium, and Synadenium were deeply nested in Euphorbia. Consequently, they were merged under Euphorbia and treated as subgenus Euphorbia sect. Monadenium, to maintain the monophyly of Euphorbia (Bruyns et al. 2006). However, the Synadenium group has been poorly sampled to date (e.g., three species in Dorsey et al. 2013).

In a field investigation targeting Kenyan Euphorbia in 2018, a shrubby Euphorbia (Synadenium) species attracted the authors' attention. At first sight, it was roughly identified as E. pseudomollis Bruyns in Bruyns et al. (2006: 414), due to its densely pubescent leaves. More specimens of this Euphorbia were collected during the following field trip at the same area, and then detailed morphological studies were conducted. Based on the floral records and the examination of Synadenium specimens deposited in herbaria worldwide, we found that this Euphorbia differs from E. pseudomollis by a combination of several morphological characters. Furthermore, the molecular phylogeny of the Synadenium group based on complete sequences of the nuclear ribosomal DNA (nrDNA) revealed that our Euphorbia collection is sister to E. bicompacta Bruyns var. bicompacta Bruyns in Bruyns et al. (2006: 412). Hence, both morphological studies and phylogenetic analyses indicate that our Euphorbia collections represent a hitherto undescribed species, which we now proceed to describe and name as Euphorbia mbuinzauensis. 


\section{Materials and methods}

\section{Morphological observations}

The morphological description of the new species is based on measurements on living specimens collected during the field trips, except for the seeds which were obtained by observations of specimens in herbaria. Comparisons with other relevant Euphorbia species were based on previous regional floristic accounts (Brown et al. 1909; Carter 1988; Carter and Leach 2001) as well as the examination of herbarium specimens and digitized images which are mainly from AMD, BR, BM, EA, HIB, K, P, S, and WAG (herbarium acronyms following Thiers (2021)).

\section{Sampling, genomic DNA extraction, and sequencing}

To delineate the phylogenetic placement of our Euphorbia collection, a total of 17 sequences, which were all newly generated in this study, were used to infer the phylogenetic tree for the Synadenium group in Euphorbia. Amongst these sequences, 14 accessions representing nine accepted species of the Synadenium-group were included. The remaining three accessions from traditionally recognized Euphorbia, Monadenium and Endadenium, were treated as outgroups, according to Dorsey et al. (2013) and Wei et al. (2021).

Sources of DNA were silica-dried leaves collected from field trips, or from dried voucher specimens in herbaria. Total genomic DNA was extracted with the MagicMag Genomic DNA Micro Kit (Sangon Biotech Co., Shanghai, China) following the instructions of the manufacturer's protocol. DNA quality was assessed by $1 \%$ agarose gel electrophoresis. Short inserts (350 bp) were used to construct paired-end 150-bp sequencing libraries using the NEBNext Ultra DNA Library Prep Kit for Illumina (NEB, United States). Libraries were sequenced at Beijing Genomics Institute (Shenzhen, China) using the Illumina HiSeq 2000 Platform (Illumina, San Diego, CA, United States).

\section{Nuclear ribosomal DNA (nrDNA) assembly and annotation}

Raw sequences were quality filtered using software Trimmomatic v.0.33 (Bolger et al. 2014), to avoid any potential sequencing artefacts, improve uniformity in the read length (> $50 \mathrm{bp}$ ) and warrant quality (Phred score > 30) in the following assemblies. FastQC 0.11.8 (http://www.bioinformatics.babraham.ac.uk/projects/fastqc/) was used to assess the trimming quality. The remaining high-quality trimmed sequences were then de novo assembled in GetOrganelle (Jin et al. 2020). The produced scaffolds were viewed and then exported as the complete nrDNA in Bandage v.0.7.1 (Wick et al. 2015). The derived nrDNA sequences were annotated in Geneious v.8.0.2 (Kearse et al. 2012) against the annotated nrDNA from other members of Malpighiales in GenBank (Linum usitatissimum EU307117; Hirtella physophora KJ414478) as references. 
The annotated accessions were prepared with GB2sequin (Lehwark and Greiner 2019) for GenBank submission. The complete nrDNA repeat sequence, including its seven constituent loci, i.e., external transcribed spacer (ETS), 18S, internal transcribed spacer 1 (ITS1), 5.8S, internal transcribed spacer 2 (ITS2), 26S, and intergenic spacer (IGS), was used to perform phylogenetic analyses. The sampled species, voucher information, and GenBank accession numbers are provided in Suppl. material 1.

\section{Molecular phylogenetic analyses}

The complete nrDNA sequences were aligned by MAFFT v. 7 (Katoh and Standley 2013) with the default setting. TrimAl v.1.2 (Capella-Gutierrez et al. 2009) was used to trim the alignment sequence with automatd 1 mode to reduce potentially poorly aligned regions. Besides, the trimmed alignments were also visually inspected in Geneious 8.0.2 (Kearse et al. 2012) and manually adjusted if necessary. PartitionFinder 2 (Lanfear et al. 2012, 2016) was used for best-fit substitution model selection for each region under the Akaike Information Criterion: the general time reversible model with a gamma distribution of substitution rates $(G T R+G)$ was chosen for the ETS region; the GTR $+\mathrm{I}+\mathrm{G}$ model with a proportion of invariant sites was selected for the $5.8 \mathrm{~S}$ and $28 \mathrm{~S}$ regions; the Hasegawa-Kishino-Yano model with a proportion of invariant sites $(\mathrm{HKY}+\mathrm{I})$ was selected for the ITS1, ITS2, and IGS regions; and the $\mathrm{HKY}+\mathrm{I}+\mathrm{G}$ model with a gamma distribution of substitution rates was selected for the $18 \mathrm{~S}$ region. The ML tree was inferred by IQ-TREE v.1.6.8 (Nguyen et al. 2015 ) with 10,000 bootstrap replicates. The BI phylogenetic analysis was performed with MrBayes v.3.2.7 (Ronquist et al. 2012). Two independent Markov Chain Monte Carlo analyses (MCMC) were run with four simultaneous chains of 10 million generations, sampling one tree every 100 generations, and setting the burnin fraction as 0.25 . The remaining trees were then used to construct a majority-rule consensus tree. The average deviation of split frequencies was verified by reaching a value below 0.01 at the end of the MCMC analyses. The effective sample sizes (ESS values > 200) for all parameters and statistics were also assessed using Tracer v.1.7.1 (Rambaut et al. 2018). The final phylogenetic tree was shown using the online tool iTOL (Letunic and Bork 2007).

\section{Results}

\section{Phylogenetic relationships}

The 17 complete nrDNA repeat sequences have average coverage ranging from 430.5 to 524.9 (Suppl. material 1). The aligned length of the seven concatenated nrDNA constituent loci dataset prior to trimming is $11,671 \mathrm{bp}$, whereas the trimmed alignment dataset consisted of 10,605 bp (Suppl. material 2) with 293 


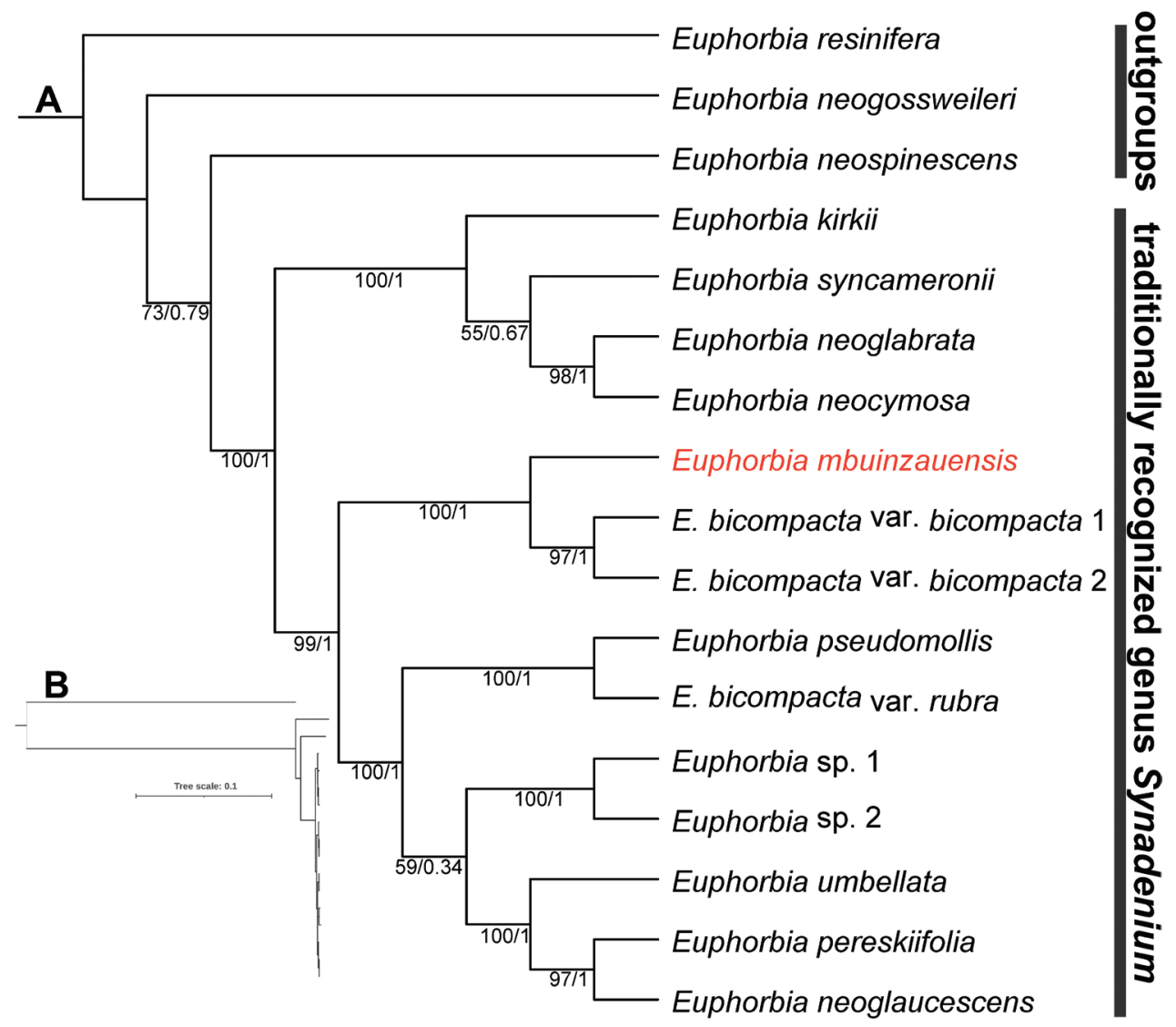

Figure I. A The maximum likelihood tree inferred from the complete nuclear ribosomal DNA sequences to elucidate the phylogenetic position of Euphorbia mbuinzauensis. Bootstrap and Bayesian posterior probability values are shown below the branches (BS/PP). The new species is highlighted in red $\mathbf{B}$ same tree as A showing branch lengths proportional to nucleotide substitutions per site.

parsimony-informative sites. The ML and $\mathrm{BI}$ trees are identical, and the ML tree with both posterior probabilities and ML bootstrap values for each clade is shown as Figure 1. For the ML analysis of the combined seven loci of nrDNA, likelihood score $(-\ln L)$ is 23609.7 . Overall, the 14 accessions of the Synadenium group clustered together and formed a strongly supported monophyletic group (BS $=100 \%$, $\mathrm{PP}=1$ ). The new species, Euphorbia mbuinzauensis, is sister to the clade that consists of two accessions of E. bicompacta var. bicompacta with robust support (BS $=100 \%, \mathrm{PP}=1)$. Despite the new species being morphologically closest to $E$. pseudomollis, they were not sister taxa in our phylogenetic tree. In addition, the accession of E. bicompacta var. rubra did not form a clade with E. bicompacta var. bicompacta as expected. Instead, it is sister to another species, E. pseudomollis, with robust support $(\mathrm{BS}=100 \%, \mathrm{PP}=1)$. 
Table I. Characters distinguishing Euphorbia mbuinzauensis from E. pseudomollis and E. bicompacta var. bicompacta.

\begin{tabular}{|c|c|c|c|}
\hline Character & E. mbuinzauensis & E. pseudomollis & E. bicompacta var. bicompacta \\
\hline Habit & Shrub to $4 \mathrm{~m}$ & Shrubby tree to $9 \mathrm{~m}$ & Shrubby tree to $7 \mathrm{~m}$ \\
\hline $\begin{array}{l}\text { Leaf apex } \\
\text { and margin }\end{array}$ & $\begin{array}{l}\text { Apex rounded to obtuse, margin } \\
\text { slightly undulate, crenate }\end{array}$ & $\begin{array}{l}\text { Apex rounded to obtuse, margin } \\
\text { serrate }\end{array}$ & $\begin{array}{l}\text { Apex abruptly acute, margin entire, or } \\
\text { minutely toothed }\end{array}$ \\
\hline $\begin{array}{l}\text { Lamina } \\
\text { surface }\end{array}$ & $\begin{array}{c}\text { Densely pubescent on adaxial surface, } \\
\text { abaxial surfaces with densely stellate } \\
\text { hairs, occasionally tinged purplish }\end{array}$ & $\begin{array}{l}\text { Densely pubescent on both sides, } \\
\text { abaxial surfaces without flecks }\end{array}$ & $\begin{array}{c}\text { Glabrous, abaxial surfaces flecked or } \\
\text { tinged purplish }\end{array}$ \\
\hline Inflorescence & $\begin{array}{c}\text { In pseudo-umbels of 2-5 cymes; } \\
\text { cymes 2-4-forked }\end{array}$ & $\begin{array}{c}\text { In pseudo-umbels of 3-5 cymes; } \\
\text { cymes 1-2-forked }\end{array}$ & $\begin{array}{l}\text { In pseudo-umbels of up to } 6 \text { cymes; } \\
\text { cymes 2-3-forked }\end{array}$ \\
\hline Bract & Ca. $2.5 \times 3.0 \mathrm{~mm}$, dentate & $\begin{array}{c}\text { Ca. } 3.5 \times 3.5 \mathrm{~mm} \text {, entire or with a } \\
\text { few teeth }\end{array}$ & Ca. $3.0 \times 3.5 \mathrm{~mm}$, obscurely dentate \\
\hline Cyathium & Ca. $6 \mathrm{~mm}$ wide & Ca. $8 \mathrm{~mm}$ wide & Ca. $7 \mathrm{~mm}$ wide \\
\hline Gland & $\begin{array}{l}\text { Deeply furrowed and wrinkled, } \\
\text { crimson }\end{array}$ & $\begin{array}{c}\text { Distinctly grooved, with a very narrow } \\
\text { smooth margin, crimson to light red }\end{array}$ & $\begin{array}{c}\text { Shallowly and minutely grooved, } \\
\text { yellow to greenish red }\end{array}$ \\
\hline $\begin{array}{l}\text { Female } \\
\text { flower }\end{array}$ & $\begin{array}{c}\text { Styles ca. } 2.0 \mathrm{~mm} \text { long, connate at } \\
\text { the base }\end{array}$ & $\begin{array}{c}\text { Styles ca. } 1.5 \mathrm{~mm} \text {. long, connate at } \\
\text { the base }\end{array}$ & $\begin{array}{c}\text { Styles ca. } 1.8 \mathrm{~mm} . \text { long, connate to } \\
\pm \text { halfway }\end{array}$ \\
\hline Capsule & To $8 \times 7 \mathrm{~mm}$ & To $10 \times 10 \mathrm{~mm}$ & To $8 \times 7 \mathrm{~mm}$ \\
\hline Seed & Ovoid, ca. $1.8 \times 2.2 \mathrm{~mm}$ & Subglobose, ca. $2.5 \times 2.5 \mathrm{~mm}$ & Ovoid, ca. $2.8 \times 2.5 \mathrm{~mm}$ \\
\hline
\end{tabular}

\section{Morphological comparisons}

Morphologically, Euphorbia mbuinzauensis is closest to E. pseudomollis, a species that occurs in Kenya and Tanzania, but differs by a shorter habit (up to $4 \mathrm{~m}$ ), abaxial surfaces of leaves densely covered with stellate hairs, 2-4-forked cymes, smaller bracts (ca. $2.5 \times 3.0 \mathrm{~mm}$ ) with dentate margin, smaller cyathia ( $6 \mathrm{~mm}$ wide), crimson gland without narrow smooth margin, smaller fruits $(\mathrm{ca} .8 \times 7 \mathrm{~mm}$ ) and smaller ovoid seeds (ca. $1.8 \times 2.2 \mathrm{~mm}$ ). Based on the results of our phylogenetic analyses, the sister taxon of Euphorbia mbuinzauensis is E. bicompacta var. bicompacta. However, E. bicompacta var. bicompacta can be easily distinguished from E. mbuinzauensis by its glabrous leaves, shallowly and minutely grooved yellow to greenish red gland, half fused style, and larger seeds (ca. $2.8 \times 2.5 \mathrm{~mm}$ ). Further detailed morphological differences among the three species are presented in Table 1.

\section{Discussion}

Euphorbia mbuinzauensis belongs to the Synadenium group of subg. Euphorbia, which is characterized by tree-like or shrubby habit, fleshy leaves with prominent midrib, pseudo-umbels of 2-5 cymes on peduncles, cymes that are forked several times, involucral [cyathial] glands that fused in a ring-like structure, funnel-shaped involucres, and rudimentary caruncles (Brown et al. 1909; Carter 1988; Carter and Leach 2001). Euphorbia mbuinzauensis is distinct, however, from other species in Synadenium group with strong morphological and phylogenetic support.

We show the monophyly of the previously segregated genus Synadenium, using phylogenetic inference based on a nrDNA dataset. Nevertheless, a more representative 
sampling of sect. Monadenium, especially of those species that belonged traditionally to Monadenium, is needed to draw this conclusion with greater confidence. It is worth mentioning that the phylogenetic relationships among the species in Synadenium group exhibited extremely short branches (Figure 1B), indicating that this lineage is likely to have radiated very recently. Interestingly, E. bicompacta var. rubra did not form a clade with E. bicompacta var. bicompacta as expected, suggesting a problem in its taxonomic placement. A comprehensive monograph based on an extensive study of specimens and a broad phylogenetic sampling is needed before the Synadenium group can be fully understood.

\section{Taxonomic treatment}

\section{Euphorbia mbuinzauensis N. Wei, Mwachala, G.W. Hu \& Q.F. Wang, sp. nov.} urn:Isid:ipni.org:names:77220553-1

Figures 2, 3

Type. Kenya. Makueni County, Mbuinzau, 2²3'25.56"S, 3754'42"E, 970 m, 29 Sep. 2018, Sino-Africa Joint Investigation Team (SAJIT) 007200 (holotype HIB!; isotypes EA!, HIB!, K!)

Diagnosis. Euphorbia mbuinzauensis is most similar to E. pseudomollis, from which it differs by its shorter habit, up to $4 \mathrm{~m}$ (vs. to $9 \mathrm{~m}$ ), abaxial leaves surfaces with densely stellate hairs (vs. simple hairs), 2- to 4-forked cymes (vs. 1- to 2-forked), bracts ca. 2.5 $\times 3.0 \mathrm{~mm}$ (vs. ca. $3.5 \times 3.5 \mathrm{~mm}$ ), dentate margin on bract (vs. entire or with a few teeth), cyathia $6 \mathrm{~mm}$ wide (vs. $8 \mathrm{~mm}$ wide), gland without narrow smooth margin (vs. with a narrow smooth margin), fruits ca. $8 \times 7 \mathrm{~mm}$ (vs. ca. $10 \times 10 \mathrm{~mm}$ ), and ovoid seeds ca. $1.8 \times 2.2 \mathrm{~mm}$ (vs. subglobose, ca. $2.5 \times 2.5 \mathrm{~mm}$ ).

Description. Many-branched shrub to $4 \mathrm{~m}$ high. Branches cylindrical, fleshy, and marked with prominent elliptic leaf scars. Leaves fleshy, subsessile, deciduous at fruiting stage, with a pair of reduced stipules; lamina subrotund to obovate, to ca. $14 \times 6 \mathrm{~cm}$, apex rounded to obtuse with a recurved tip, margin slightly undulate, crenate, midrib distinctly keeled beneath, blade inflated, incurved, adaxial surfaces densely pubescent, green, turning to purplish grey green during dry season, abaxial surfaces densely stellate hairy, occasionally tinged purplish, with stellate hairs along the midrib. Inflorescences monoecious, in dense pseudo-umbels of 2-5 cymes on pubescent peduncles to $4 \mathrm{~cm}$ long; cymes 2-4-forked, with pubescent branches to $1.8 \mathrm{~cm}$ long; bracts subquadrate, ca. $2.5 \times 3.0 \mathrm{~mm}$, dentate, densely pubescent. Cyathia ca. $2.5 \times 6.0 \mathrm{~mm}$, with broadly funnel-shaped involucres, pubescent below; glandular rim ca. $1.2 \mathrm{~mm}$ wide, deeply furrowed and wrinkled, purplish red, mostly shallowly notched on the one side, but with a deep notch when young; lobes subquadrate, ca. $2.0 \times 2.5 \mathrm{~mm}$, purplish red, pubescent. Male flowers: staminate flowers $0.8 \mathrm{~mm}$ long, enclosed by involucral lobes and bracteoles; bracteoles fan-shaped, laciniate, plumose, $3 \mathrm{~mm}$ long, with pedicels minutely pubescent; pedicels $3 \mathrm{~mm}$ long. Female flowers: styles ca. $2 \mathrm{~mm}$ long, connate at the base, pubescent, with distinctly bifid thickened apices, deciduous in fruit. Capsules obovoid, deeply acutely lobed, apex depressed, to 


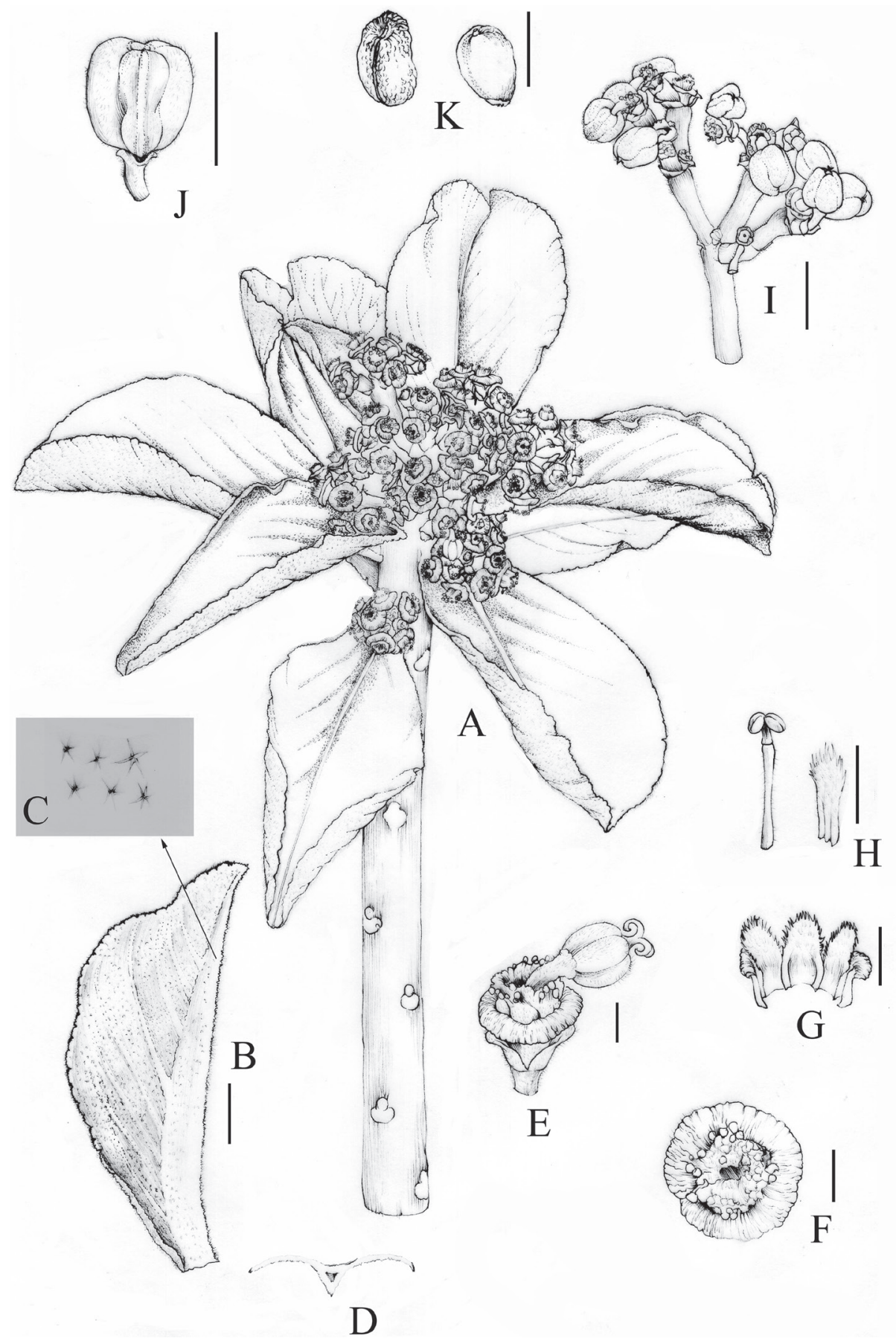

Figure 2. Euphorbia mbuinzauensis $\mathbf{A}$ flowering branch $\mathbf{B}$ leaf $\mathbf{C}$ the close-up of abaxial leaf to show densely stellate hairs $\mathbf{D}$ section through leaf to show the distinct keel on midrib beneath $\mathbf{E}$ cyathium, lateral view $\mathbf{F}$ cyathium, top view $\mathbf{G}$ dissected involucre to show lobes $\mathbf{H}$ male flower and bracteole $\mathbf{I}$ infructescence $\mathbf{J}$ fruit. K. Seeds. Scale bars: 2 mm (C-H, K); 1 cm (B, I, J). Voucher specimen: SAJIT 007200. Drawn by Nan Jia. 


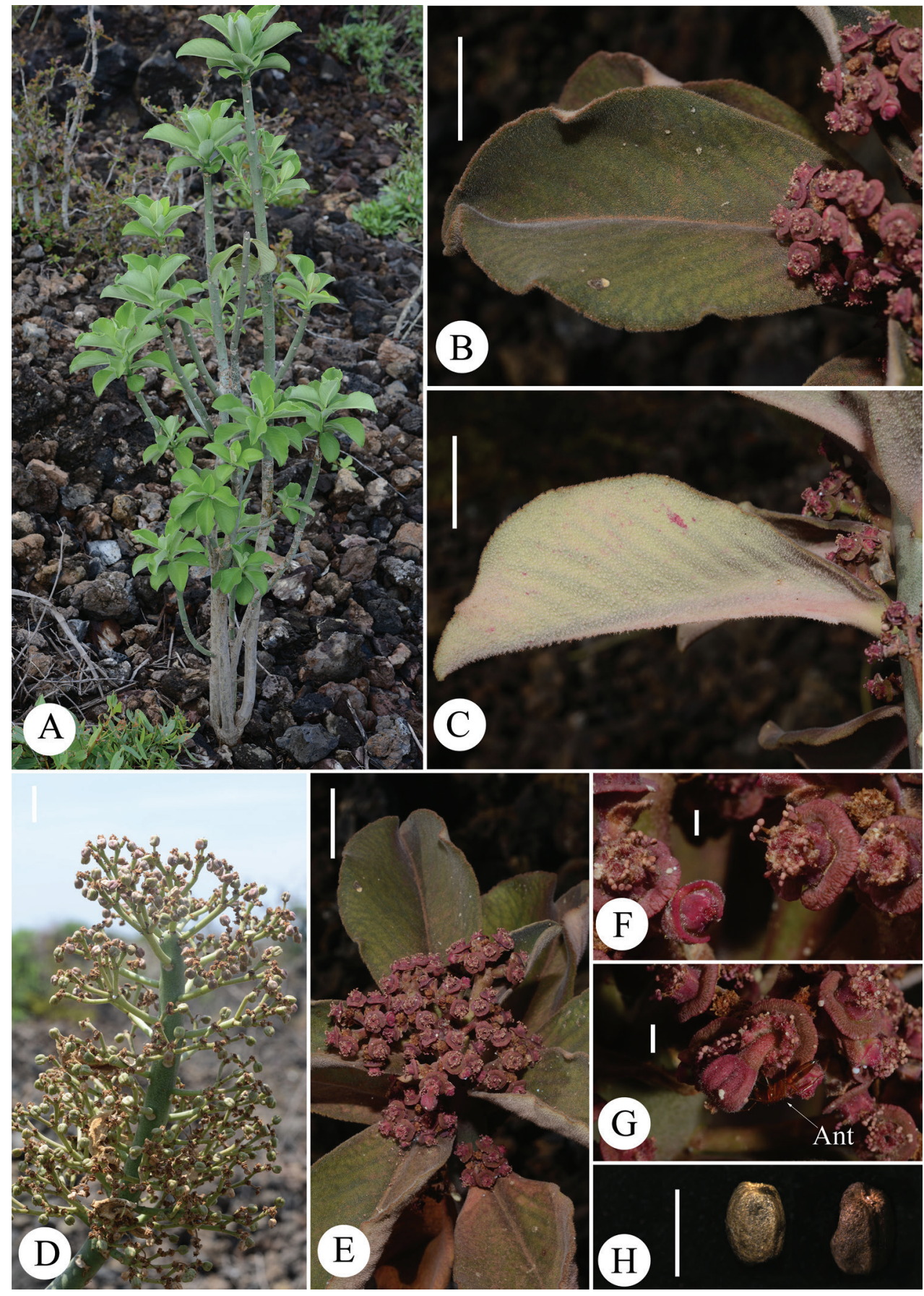

Figure 3. Morphological features of Euphorbia mbuinzauensis A habit B adaxial surface of leaf $\mathbf{C}$ abaxial surface of leaf $\mathbf{D}$ a branch with numerous infructescences $\mathbf{E}$ apical portion of flowering branch F, G Cyathium $\mathbf{H}$ seeds. Scale bars: $2 \mathrm{~mm}(\mathbf{F}-\mathbf{H}) ; 2 \mathrm{~cm}$ (B-E). Voucher specimens: SAJIT 007411 (A), SAJIT 007200 (B-H). Photo credit: Neng Wei. 
$8 \times 7 \mathrm{~mm}$, from purplish red to yellowish green, pubescent, explosively dehiscing septicidally and loculicidally into 32 -valved cocci; pedicel recurved, pubescent, to $8 \mathrm{~mm}$ long; columella persistent, 6-7 mm long. Seeds ovoid, obscurely 4-angled, ca. $1.8 \times$ $2.2 \mathrm{~mm}$, pale brown to dark brown, shallowly tuberculate; caruncle rudimentary.

Distribution and ecology. Only one population of the new species was found at the foot of Mbuinzau hill, Makueni County, Kenya (Figure 4). Here it grows in open deciduous woodlands covered by lava outcrops at an elevation of ca. $970 \mathrm{~m}$.

Conservation status. Only one population of the new species was found in an isolated woodland covered by lava outcrops (Figure 3A) in Mbuinzau area. We assess the species as Endangered (criteria D1) according to the IUCN Red List Categories and Criteria (IUCN 2001), due to the number of mature individuals $(<250)$ in a very small and restricted population. Unfortunately, the habitat is threatened by human activities. For instance, its habitat has been fragmented by the Mombasa-Nairobi Railway and Mombasa-Road, which are the busiest traffic routes in Kenya. Moreover, the population is under threat from habitat loss, due to the exploitation of lava rocks in its habitat for construction.

Phenology. Euphorbia mbuinzauensis was found with flowers in September and with fruits from September to December.

Etymology. The epithet "mbuinzauensis" refers to its type locality, Mbuinzau in Makueni County, Kenya.

Notes. The conspicuous latex is extremely poisonous to cattle as well as human beings, according to the comments from local farmers. We observed ants visiting the flowers and they are a possible pollinator to this species (Figure 3G).

Additional specimens examined (Paratypes). KENYA. Makueni County, Mbuinzau, 2²3'25.56"S, 3754'42"E, elev. 970 m, 5 Dec. 2018, SAJIT 007411 (EA!, HIB!).

Specimens examined for Euphorbia pseudomollis. KenYa. Makueni, Kibwezi, c. 1000 m, 2²6'S, 38¹'E, 22 Mar. 1906, G.Scheffler 137 (isotypes AMD [AMD.66883] image!, BM [BM000911307]!, K [K000238424]!, S [S13-12929] image!, WAG [WAG0004308] image!); Taita-Taveta, Mwatate, 3³1'S, 38²4'E, 29 Apr. 1963, P.R.O. Bally B12725 (BR [BR0000016225411] image!, K [K000238420]!); Taita-Taveta, Mwatate West of Voi, 330'S, 38²3'E, 15 Jul. 1960, L.C. Leach \& R. Bayliss 10258 (K [K000238421]! \& [K000238422]!); Kitui, Mutomo Hill Plant Sanctuary, 900$1000 \mathrm{~m}, 1^{\circ} 51^{\prime} \mathrm{S}, 38^{\circ} 13^{\prime} \mathrm{E}, 2$ May 1970, J.B. Gillett 19141 (EA!, K [K000238423]!); Taita-Taveta, Taita, Sisal Estate, Senbi Hill, 1050 m, 3³1'S, 38²4'E, 17 Aug. 2000, P.A. Luke \& W.R.Q. Luke 6432 (EA!). TANZANia. Kilimanjaro, above Mwembe, 1005 m, 4ㅇ's'S, 3751'E, 9 Apr. 1972, B.J. Harris BJH6342 (K [K000238425]!); Kilimanjaro, Mwembe, $4^{\circ} 10^{\prime} \mathrm{S}, 37^{\circ} 51^{\prime} \mathrm{E}$, unknown date, P.R.O. Bally B11499 (E54) (K [K000238426]! \& [K000238427]!); Dodoma, Mpwapwa, 1128 m, 6²1'S, 36 29'E, 30 Jun. 1938, Hornby 911 (K [K000238428]!); Tanga, Handeni, Kideleko, 609 m, $5^{\circ} 29^{\prime} S$, 38¹'E, 1 Jul. 1965, M.E. Archbold 471 (K [K000238430]!); Tanga, Handeni, Chanika Village, $700 \mathrm{~m}, 5^{\circ} 25^{\prime} \mathrm{S}, 38^{\circ} 1^{\prime} \mathrm{E}, 23$ Sep. 1979, O. Hedberg et al. TMP194 (K [K000238431]!); Morogoro, Kilombero, Lugoda, 1800 m, 842'S, 3549'E, Aug. 1988, E. Adiheysen 224 (K [K000238432]!); Iringa, a little north of Morogoro road, $1554 \mathrm{~m}, 7^{\circ} 30^{\prime} \mathrm{S}, 36^{\circ} 10^{\prime} \mathrm{E}, 27$ Feb. 1962, R.M. Polhill \& S. Paulo 1618 (BR 


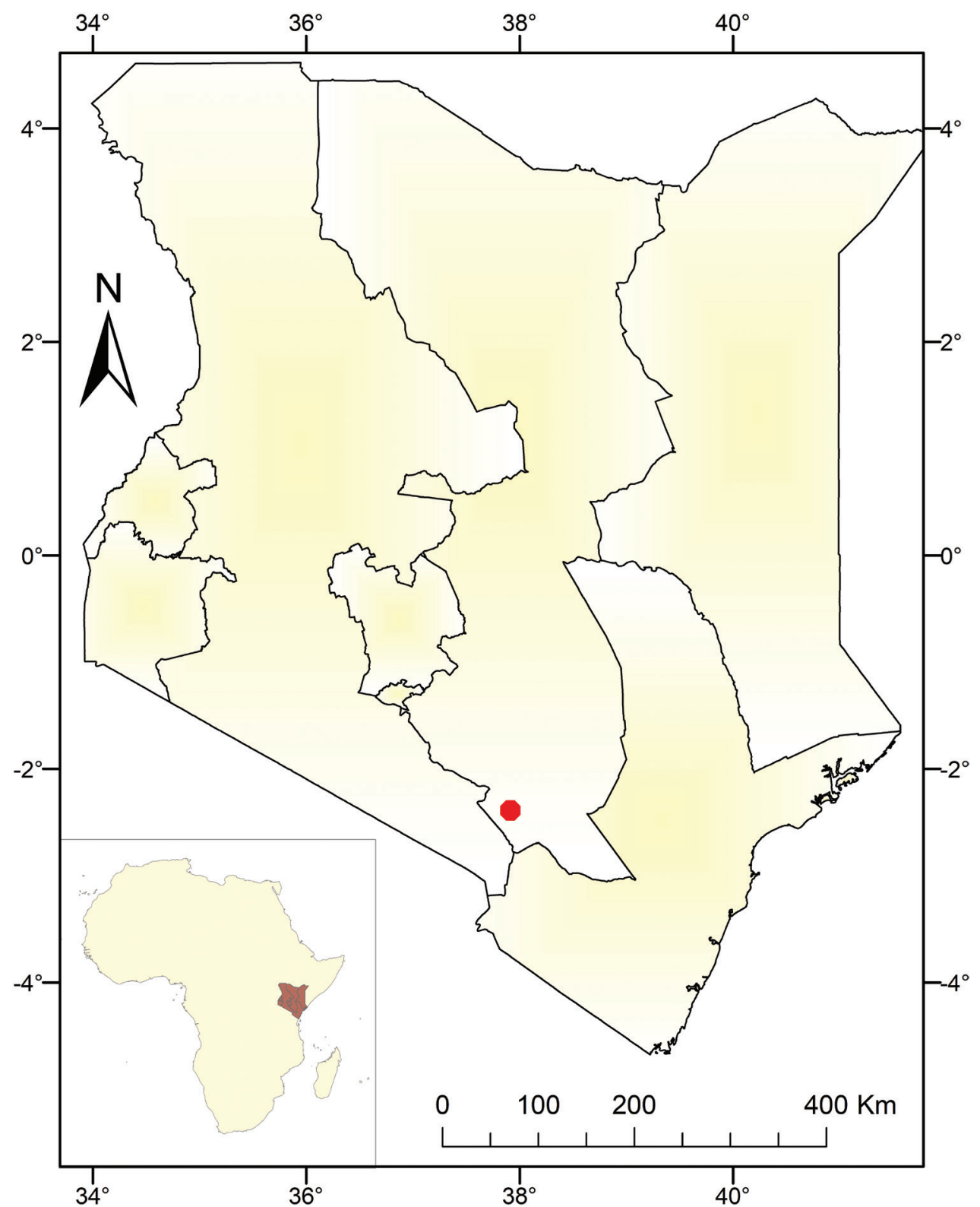

Figure 4. Known distribution of Euphorbia mbuinzauensis in Kenya. The red dot indicates its only known locality.

[BR0000016225435] image!, EA!, K [K000238433]!, P [P00581481] image!); Lindi, 22 Apr. 1933, H.J.Schlieben n6383 (BR [BR0000016225428] image!).

Specimens examined for Euphorbia bicompacta var. bicompacta: KENYA. Machakos, $1^{\circ} 31^{\prime} S, 37^{\circ} 16^{\prime} \mathrm{E}, 7$ Jun. 1902, T. Kassner 956 (Holotype K [K000237846]!; Isotype BM [BM000911306]!); Taita-Taveta, Wusi, $1371 \mathrm{~m}, 3^{\circ} 27^{\prime} \mathrm{S}, 38^{\circ} 21^{\prime} \mathrm{E}$, May 1931, ERN 
1322 (K [K000237843]!); Machakos, $1^{\circ} 31^{\prime}$ S, 37016'E, 27 Mar. 1940, P.R.O. Bally E144 (K [K000237845]!); Makueni, Kibwezi, Sisal Estate, 914 m, 2²6'S, 38²1'E, Jun. 1943, P.R. O. Bally B2573 (K [K000237847]!); Kitui, Migwani, 10 miles N of Migwani on Tharaka road, 057'18"S, 38¹'9"E, 3 May 1960, D.M. Napper 1596 (BR [BR0000016224810] image!, EA!, K [K000237848]!); Nairobi, Nairobi arboretum, 1768 m, 1²17'S, 36²49'E, Aug. 1932, I.R. Dale 2887 (K [K000237849]!); Nairobi, Langata, 1 ${ }^{\circ} 20^{\prime} \mathrm{S}, 36^{\circ} 46^{\prime} \mathrm{E}$, 20 March 1963, P.R.O. Bally B12659 (K [K000237850]!); Kiambu, Muguga, $1^{\circ} 11^{\prime} \mathrm{S}$, $36^{\circ} 38^{\prime} \mathrm{E}, 8$ Jun. 1962, J. Gichuru 14 (K [K000237851]!); Nyeri, Karatina, $0^{\circ} 29^{\prime} \mathrm{S}, 37^{\circ} 8^{\prime} \mathrm{E}$, 24 Apr. 1943, P.R.O. Bally B2541 (EA!, K [K000237852]!); Embu, Thuchi, crossing on Embu-Meru road, 760 m, 0²5'S, 3752'E, 4 Apr. 1970, J.B. Gillett \& B. Mathew 19063 (BR [BR0000016224803] image!, K [K000237853]!); Laikipia, Kisima farm, 1700 m, $0^{\circ} 30^{\prime}$ S, 36 30'E, 14 Jun. 1972, P.R.O. Bally B15106 (K [K000237854]!); Taita-Taveta, Msau River Valley, 800-950 m, 324'S, 38²4'E, 18 May 1985, C.H.S. Kabuye et al. 743 (K [K000237855]!); Taita-Taveta, Kasigau Mountain, 1000 m, 350'S, 3840'E, 31 May 1998, W.R.Q. Luke et al. 5344 (K [K000237856]!); Elgeyo Marakwet, Arror lower, Pt 203, 1050 m, 10'55"S, 35³7'27"E, 30 Jul. 2017, Mwadime N 1861 (EA!).

\section{Acknowledgements}

We thank Leonard E. Newton and Susan Carter for their valuable comments and suggestions. We also thank Paul Rees, Imalka Kahandawala, and Zhengwei Wang for their help in collecting material for DNA extraction. Gratitude is extended to Mrs. Nan Jia for her beautiful line drawings of the new species; Mrs. Lunlun Gao from Huazhong Agricultural University for preparing the distribution map; and the Kenya Forest Service (KFS) for issuing fieldwork permits (permit number: RESEA/1/KFS 98 and RESEA/1/KFS 22) to conduct the field investigations. We would also like to thank the following herbaria AMD, BR, BM, EA, HIB, K, P, S, and WAG for hosting our visits or providing images of digitized specimens in this study. We are grateful to Dr. Dmitry Geltman for his significant editorial work, Dr. Kenneth J. Wurdack and an anonymous reviewer for their constructive comments, which helped us to improve the manuscript. This work was supported by grants from Sino-Africa Joint Research Center, CAS, China [grant numbers SAJC202101], International Partnership Program of Chinese Academy of Sciences [grant numbers 151853KYSB20190027], the National Science Foundation of China [grant number 31970211 and 32070231] and the University of Chinese Academy of Sciences Joint PhD Training Program.

\section{References}

Bolger AM, Lohse M, Usadel B (2014) Trimmomatic: A flexible trimmer for Illumina sequence data. Bioinformatics (Oxford, England) 30(15): 2114-2120. https://doi.org/10.1093/bioinformatics/btu170 
Brown NE, Hutchinson J, Prain D (1909) Euphorbiaceae. In: Oliver D (Ed.) Flora of tropical Africa, vol. 6. L. Reeve and co., London, 441-1020.

Bruyns PV, Mapaya RJ, Hedderson TJ (2006) A new subgeneric classification for Euphorbia (Euphorbiaceae) in southern Africa based on ITS and $p s b A$-trnH sequence data. Taxon 55(2): 397-420. https://doi.org/10.2307/25065587

Bruyns PV, Klak C, Hanáček P (2011) Age and diversity in Old World succulent species of Euphorbia (Euphorbiaceae). Taxon 60(6): 1717-1733. https://doi.org/10.1002/tax.606016

Capella-Gutierrez S, Silla-Martinez JM, Gabaldon T (2009) TrimAl: A tool for automated alignment trimming in large-scale phylogenetic analyses. Bioinformatics (Oxford, England) 25(15): 1972-1973. https://doi.org/10.1093/bioinformatics/btp348

Carter S (1988) Euphorbieae. In: Polhill RM (Ed.) Flora of Tropical East Africa, Euphorbiaceae (Part 2). A.A. Balkema, Rotterdam, 409-564.

Carter S, Leach LC (2001) Euphorbieae. In: Pope GV (Ed.) Flora Zambesiaca. Royal Botanic Gardens, Kew, Richmond, 339-465.

Croizat L (1972) An introduction to the subgeneric classification of Euphorbia L., with stress on the South African and Malagasy species. Webbia 27(1): 1-221. https://doi.org/10.108 0/00837792.1972.10669972

de Candolle ALPP (1862) Prodromus systematis naturalis regni vegetabilis, sive enumeratio contracta ordinum, generum, specierumque plantarum hucusque cognitarum, juxta methodi naturalis normas digesta 15(2). Treuttel et Würtz, Paris, 1286 pp. https://doi. org/10.5962/bhl.title.286

Dorsey BL, Haevermans T, Aubriot X, Morawetz JJ, Riina R, Steinmann VW, Berry PE (2013) Phylogenetics, morphological evolution, and classification of Euphorbia subgenus Euphorbia. Taxon 62(2): 291-315. https://doi.org/10.12705/622.1

Govaerts R, Frodin DG, Radcliffe-Smith A, Carter S (2000) World checklist and bibliography of Euphorbiaceae (with Pandaceae). Royal Botanic Gardens, Kew, 415 pp.

Horn JW, van Ee BW, Morawetz JJ, Riina R, Steinmann VW, Berry PE, Wurdack KJ (2012) Phylogenetics and the evolution of major structural characters in the giant genus Euphorbia L. (Euphorbiaceae). Molecular Phylogenetics and Evolution 63(2): 305-326. https://doi. org/10.1016/j.ympev.2011.12.022

IUCN (2001) IUCN Red List Categories and Criteria, Version 3.1. IUCN Species Survival Commission, Gland, Switzerland and Cambridge, United Kingdom, 30 pp.

Jin JJ, Yu WB, Yang JB, Song Y, Depamphilis CW, Yi TS, Li DZ (2020) GetOrganelle: A fast and versatile toolkit for accurate de novo assembly of organelle genomes. Genome Biology 21(1): e241. https://doi.org/10.1186/s13059-020-02154-5

Jones K, Smith JB (1969) The Chromosome Identity of Monadenium Pax and Synadenium Pax (Euphorbiaceae). Kew Bulletin 23(3): 491-498. https://doi.org/10.2307/4117196

Katoh K, Standley DM (2013) MAFFT multiple sequence alignment software version 7: Improvements in performance and usability. Molecular Biology and Evolution 30(4): 772-780. https://doi.org/10.1093/molbev/mst010

Kearse M, Moir R, Wilson A, Stones-Havas S, Cheung M, Sturrock S, Buxton S, Cooper A, Markowitz S, Duran C, Thierer T, Ashton B, Meintjes P, Drummond A (2012) Geneious Basic: An integrated and extendable desktop software platform for the organization and 
analysis of sequence data. Bioinformatics (Oxford, England) 28(12): 1647-1649. https:// doi.org/10.1093/bioinformatics/bts199

Lanfear R, Calcott B, Ho SY, Guindon S (2012) PartitionFinder: Combined selection of partitioning schemes and substitution models for phylogenetic analyses. Molecular Biology and Evolution 29(6): 1695-1701. https://doi.org/10.1093/molbev/mss020

Lanfear R, Frandsen PB, Wright AM, Senfeld T, Calcott B (2016) PartitionFinder 2: New methods for selecting partitioned models of evolution formolecular and morphological phylogenetic analyses. Molecular Biology and Evolution 34: 772-773. https://doi. org $/ 10.1093 / \mathrm{molbev} / \mathrm{msw} 260$

Lehwark P, Greiner S (2019) GB2sequin -A file converter preparing custom GenBank files for database submission. Genomics 111(4): 759-761. https://doi.org/10.1016/j.ygeno.2018.05.003

Letunic I, Bork P (2007) Interactive Tree Of Life (iTOL): An online tool for phylogenetic tree display and annotation. Bioinformatics (Oxford, England) 23(1): 127-128. https://doi. org/10.1093/bioinformatics/bt1529

Nguyen LT, Schmidt HA, von Haeseler A, Minh BQ (2015) IQ-TREE: A fast and effective stochastic algorithm for estimating maximum-likelihood phylogenies. Molecular Biology and Evolution 32(1): 268-274. https://doi.org/10.1093/molbev/msu300

Rambaut A, Drummond AJ, Xie D, Baele G, Suchard MA (2018) Posterior summarization in Bayesian phylogenetics using Tracer 1.7. Systematic Biology 67(5): 901-904. https://doi. org/10.1093/sysbio/syy032

Ronquist F, Teslenko M, van der Mark P, Ayres DL, Darling A, Hohna S, Larget B, Liu L, Suchard MA, Huelsenbeck JP (2012) MrBayes 3.2: Efficient Bayesian phylogenetic inference and model choice across a large model space. Systematic Biology 61(3): 539-542. https://doi.org/10.1093/sysbio/sys029

Steinmann VW, Porter JM (2002) Phylogenetic relationships in Euphorbieae (Euphorbiaceae) based on ITS and $n d h F$ sequence data. Annals of the Missouri Botanical Garden 89(4): 453-490. https://doi.org/10.2307/3298591

Thiers B (2021, onwards) Index herbariorum: a global directory of public herbaria and associated staff. New York Botanical Garden's Virtual Herbarium. http://sweetgum.nybg.org/ science/ih/ [accessed 2 May 2021]

Webster GL (1967) The genera of Euphorbiaceae in the southeastern United States. Journal of the Arnold Arboretum 48: 363-430. https://www.jstor.org/stable/43782494

Wei N, Pérez-Escobar OA, Musili PM, Huang WC, Yang JB, Hu AQ, Hu GW, Grace OM, Wang QF (2021) Plastome evolution in the hyperdiverse genus Euphorbia (Euphorbiaceae) using phylogenomic and comparative analyses: Large-scale expansion and contraction of the inverted repeat region. Frontiers in Plant Science 12: e712064. https://doi. org/10.3389/fpls.2021.712064

Wick RR, Schultz MB, Zobel J, Holt KE (2015) Bandage: Interactive visualization of de novo genome assemblies. Bioinformatics (Oxford, England) 31(20): 3350-3352. https://doi. org/10.1093/bioinformatics/btv383

Zimmermann NFA, Ritz CM, Hellwig FH (2010) Further support for the phylogenetic relationships within Euphorbia L. (Euphorbiaceae) from nrITS and trnL-trnFIGS sequence data. Plant Systematics and Evolution 286(1-2): 39-58. https://doi.org/10.1007/s00606-010-0272-7 


\section{Supplementary material I}

\section{Table $\mathbf{S 1}$}

Authors: Neng Wei, Fredrick Munyao Mutie, Geoffrey Mwachala, Olwen M. Grace, Guang-Wan Hu, Qing-Feng Wang

Data type: docx. file

Explanation note: Accessions of nuclear ribosomal DNA (nrDNA) in Euphorbia used in this study. (SCBG indicates Shanghai Chenshan Botanical Garden, Chinese Academy of Sciences).

Copyright notice: This dataset is made available under the Open Database License (http://opendatacommons.org/licenses/odbl/1.0/). The Open Database License $(\mathrm{ODbL})$ is a license agreement intended to allow users to freely share, modify, and use this Dataset while maintaining this same freedom for others, provided that the original source and author(s) are credited.

Link: https://doi.org/10.3897/phytokeys.183.70285.suppl1

\section{Supplementary material 2}

\section{File 2}

Authors: Neng Wei, Fredrick Munyao Mutie, Geoffrey Mwachala, Olwen M. Grace, Guang-Wan Hu, Qing-Feng Wang

Data type: docx. file

Explanation note: The trimmed alignment of the 17 complete nuclear ribosomal DNA (nrDNA) sequence dataset in nexus format.

Copyright notice: This dataset is made available under the Open Database License (http://opendatacommons.org/licenses/odbl/1.0/). The Open Database License $(\mathrm{ODbL})$ is a license agreement intended to allow users to freely share, modify, and use this Dataset while maintaining this same freedom for others, provided that the original source and author(s) are credited.

Link: https://doi.org/10.3897/phytokeys.183.70285.suppl2 